\title{
A Macro Economic Analysis of the Demand for Money in Nigeria
}

\author{
Danladi Jonathan PhD Awopetu, Olayinka Bobola \\ Department of Economics, Afe Babalola University, Ado Ekiti (ABUAD), Nigeria
}

\begin{abstract}
The demand for money plays a very essential role in macroeconomic analysis. This paper expresses a mathematical relationship between the quantity of money demanded and its various determinants which are; interest rate, income, price level, credit availability, frequency of payments, etc The analysis was done using the Vector Autoregressive method. The ADF and KPSS unit root tests were conducted. The co-integration test was established using the Johansen co-integration test. The study shows how the demand for money responds to shock in itself, shock in interest rate, shock in credit to private sector, shock in credit to government, and shock in domestic assets. The study also discovered that money demand has a major effect on the aggregate demand which accounts for the Gross Domestic Product (GDP) of the economy. This explains that by ensuring efficiency in demand for money, aggregate demand would be achieved and adequate sustained growth also will be achieved within the economy.
\end{abstract}

Keywords: Interest Rate, Gross Domestic Product (GDP), Income, Aggregate Demand and Price.

DOI: $10.7176 / \mathrm{JESD} / 11-6-05$

Publication date:March $31^{\text {st }} 2020$

\subsection{Introduction}

The demand for money is the desire to carry financial assets within the sort of money: which is, cash or bank deposits instead of investments. The concept of "money demand" has over the years attracted the interest of great economists. It is a really crucial instrument within the conduct and determination of the effectiveness of monetary policy. The demand for money unlike the demand for goods is not restricted to one market but also involves other markets (i.e. money market, capital market, commodity market and foreign exchange market), hence it has a direct bearing on monetary policy and so relevant to the study of macro-economics. The focus of the demand for money is attributed to the fact that monetary policy will only be effective if the demand for money function is stable. According to John Maynard Keynes, money is demanded for many purposes; transactionary, precautionary and speculative. Corresponding to each purpose, there is often demand for a few amount of cash.

Today, some of the policy-related developments that motivated the rigorous investigation of demand for money in Nigeria have not changed substantially. For example, the Central Bank of Nigeria (CBN) in 1974 adopted monetary targeting as the framework for the implementation of monetary policy. One of the key requirements for a successful targeting of monetary aggregates is the stability of money demand (Anoruo 2002, and Khan and Ali 1997). Till date, the Central Bank of Nigeria has continued to target money as its main monetary policy strategy.

In an open economy, money is considered as a part of portfolio, which consists of domestic financial assets, and foreign assets. The return on the domestic money is the rate of interest. The return on real assets is that the expected rate of inflation. According to Freidman (1956), the purchasing power of money erodes quickly under high inflation, while the value of real assets is maintained, and as a result, economic agents may wish to switch into real assets when the inflationary expectations are strong. Friedman also opined that investors can hold their wealth in the form of money, bonds, equities and commodities. He believed that wealth must be variable in the money demand function and he used permanent income, a weighted average of current and past levels of income, as an alternative within the absence of an immediate estimate of wealth.

Mai-Lafia (2002), while examining the cost of credit (interest rate) in Nigeria pointed the fact the interest rate dispute is related to allocation of savings between money and other financial assets. That there is exists an inverse relationship between the desire to hold money and the desire to invest. Borrowers in need of credit are ready to attract such funds from savers goodbye as they achieve creating money substitutes which have the effect of reducing the demand for money as a sort of holding wealth.

Carpenter and Lange (2002) introduced two indicators of equity market conditions, the volatility in equity prices and revisions to analysts' earnings expectations, into a money demand model. Assuming that agents are risk averse, volatility in the value of an asset tends to make that asset less attractive, Ceteris Paribus, and thus could push investors into safer alternative assets. Similarly, equity prices are a function of the discounted future earnings of the corporate. Money demand in part reflects a portfolio decision. As equities have become a significant store of wealth, it seems plausible that variations in equity markets could affect money demand. Carpenter and Lange also re- specified a standard money demand equation to include stock market earnings projections. They acknowledged that those equity market variables are statistically and economically significant within the money demand equation (for USA) from early 90 s to 2002. Their conclusion is that the inclusion of those variables tightens the estimated money demand equation.

Nevertheless, every fresh attempt at studying the demand for money in Nigeria must be vigorously justified. 
The demand for money itself may be a dynamic phenomenon. These determinants of money demand change over time especially when we consider the growing trends in financial innovation. In the past, many studies had, for example reported interest rate neutrality in the demand for money function in Nigeria owing to the undeveloped nature of the financial market and narrow range of financial assets, such that rather than substituting between cash and physical assets, economic agents tended to substitute between cash and physical assets. This paper is aimed at re-assessing the demand for money in Nigeria in the light of recent developments in the economy including the rapid expansion in incomes, greater number and variety of financial assets, and increased openness of the Nigerian Economy.

\subsection{Literature Review}

\subsection{Theoretical Literature Review}

The literature on the demand for money, also referred to as the demand for real balances is quite vast. At the theoretical level, the motives for holding money are clearly distinguished; transactions, speculative and precautionary motives. The Keynesian theory (1936) identifies all three motives for holding cash balances. Both the post-Keynesian and the classical quantity theories, however, focus on particular motives for holding money in explaining the determination of money demand. (Tiegen, 1971).

Keynes argued that economic agents hold certain proportion of money for the sake of medium of exchange function. That is, to effect transactions. This motive is viewed as dependent on income. The relationship between the transactions demand for money and income is postulated to be stable. Cash balances also are held to bridge receipts and payments since people are sometimes unsure when they would have needed to form payments. Precautionary motive, according to Keynes depends on the level of income. The third motive for holding money in the Keynesian theory of demand for money is speculative purposes. He argued that individuals hold cash balances in order to invest or speculate. This depends on expectation about future (or expected) rates of interest.

Laidler (1977) was of the view that Keynes did not regard the demand for money arising from the transactionary and precautionary motives as technically fixed in their relationships with the level of income and thus emphasizes that the foremost important innovation in Keynes' analysis is his speculative demand for money. The Keynesian speculative primary result shows that there is a negative relationship between money demand and the rate of interest.

One major issue that has influenced money demand in Nigeria is the introduction of economic reforms. Since the economic reform measures started, several studies are administered on the demand for money in Nigeria, though not all made explicit attempts at investigating the steadiness of money demand function. Asogu and Mordi (1987) examined the monetary sector generally to get some major determinants of cash demand function. Ikhide and Fajingbesi (1998) also examined interest rate deregulation in Nigeria to see whether it is of major significance in the money demand function in Nigeria. Essien, Onwioduokit and Osho (1996), in their work on the demand for money during a debt- constraint economy observed that indebtedness could signal to non-public economic agents the direction of government fiscal and monetary policy which in turn influences the demand for money in the domestic economy. Audu (1988) in a search on selected West African Countries observed that for Nigeria, a stable money demand relationship exists.

A recurring debate within the literature on the effectiveness of monetary policy to stabilize within the Nigerian economy in terms of price stability and subsequently stimulating economic process is the nature and stability of money demand function (Bursary 2006). This debate started within the early 1970s amongst a gaggle of students in Nigeria in what's popularly mentioned because the "TATTOO DEBATE". Tomori (1972), discovered income, interest rate and real income to be the major determinants of demand for money in Nigeria.

Mai-Lafia, (1995) argued that there is an inverse relationship between the desire to hold money and desire to invest. Borrowers are in need of credit and so they create money substitutes which have the effect of reducing the demand for money as a form of holding wealth. He used shares as an example and stated that if they are close money substitutes, an increase in distributed dividends will cause a reduction in the demand for cash balances and this may successively favour investment of such excess in shares. Lee (1967) asserts that the demand for money is usually sensitive to changes within the yield of savings and loan shares. Hamburger (1966), suggest that he is enabled to reject the hypothesis that equities and financial assets including short and long term marketable bonds and the liabilities of financial intermediaries are equally effective substitutes for money.

Like other financial assets, demand for money is part of a portfolio allocation decision, in which an agent's wealth is distributed among competing assets based on each other's relative benefits (Tobin1969). To a particular extent, agents are willing to offer up the upper return of other assets so as to receive the advantage of liquidity that cash provides.

Chukwu (2009) argues that the economic environment that guided monetary policy before 1986 was characterized by the dominance of the oil sector, the expanding role of the general public sector in the economy and over- dependence on the external sector. In order to take care of price stability and a healthy balance of payments position, monetary management trusted the utilization of direct monetary instruments like credit ceilings, 
selective credit controls ,administered interest and exchange rates, also because the prescription of money reserve requirements and special deposits. According to Al- Samara (2011), the money demand function is considered as a key factor in conducting reliable strategy of monetary policy and selecting the suitable nominal anchor that monetary makers use to tie down the price level. The marvelous step in monetary analysis showed why a nominal anchor, such as the inflation rate, exchange rate, or the money supply is such a crucial element in achieving the price stability.

\subsection{Empirical Literature Review}

The empirical literature on the demand for money in Nigeria is quite vast. A number of studies have examined the stability of money demand function in the context of cointegration analysis. Bahamani- Oskooee and Bohl (2000) analyzed the steadiness of M3 money demand function for Germany following the monetary unification. Their results indicated that M3 money demand function in Germany isn't stable. Bahamani- Oskooee and Barry (2000) investigated the steadiness of the M2 money demand function in Russia. They found evidence of cointegration between the series in the system, while the plot of the cumulative sum of recursive residuals (CUSUM) provided evidence of stability, the plot of the cumulative sum of squares of recursive residuals (CUSUMSQ), on the other hand revealed that M2 function is not stable.

Nell (1999) empirically evaluated the existence of a stable end of the day demand for money function in South Africa over the period 1965 -1997, as long as after the adoption of cash market oriented monetary policy measures in 1980, South Africa Federal Reserve Bank primarily relied on setting predetermined growth targets for M3. The empirical results suggest that M3 was stable while M1and M2 displays parameter instability. This suggests that M3 money stock could function an indicator for monetary policy for South Africa. Adam (1992) successfully established a series of single equation demand for money functions (M0, M1, M2 and M3) for the Kenyan economy from 1973 to 1989.

According to Ajayi (1977), "The demand for money is inelastic with respect to income and price changes expectation. Using the OLS model, he discovered that there is an unstable money demand, Real income and real interest rate in the aggregate $\mathrm{M} 2$.

Al- Samara (2011), in his study in the analysis of money demand function in Syria found that real money demand M2 and its economics determinants are weakly cointegrated. On the other hand, stability test and error correction model have provided a support that cash demand function is unstable within the Syrian economy, and this instability might be as a result of structural changes in the function. Anoruo (2002) explored the steadiness of the M2 money demand function in Nigeria within the SAP period and his results from the Johansen and Juselius (1990) cointegration test suggested that real discount rates, economic activity and real M2, are cointegrated. The results of the study showed that M2 is a viable monetary policy tool that could be used to stimulate economic activity in Nigeria. The earliest studies on the demand for money in Nigeria referred to as the TATOO debate essentially focused on definition of money, income as a key variable and a bit of stability issues (Yamden, 2011). Nwaobi (2002) has also made efforts to examine the stability of the Nigeria's money demand function and found it to be stable. He then suggested that monetary policy could be effective and that income is an appropriate determinant in the estimation of money demand in Nigeria. According to Mai- Lafia, (1995), there is an inverse relationship between the desire to hold money and desire to invest. Borrowers are in need of credit then they create money substitutes which have the effect of reducing the demand for money as a form of holding wealth. He used shares as an example and stated that if they are close substitutes, an increase in distributed dividends will induce a reduction in the demand for cash balances and this may successively favour investment of such excess in shares.

\subsection{Methodology and Theoretical Framework}

The theoretical framework adopted in this study is the Keynesian theory of demand for money, which is also called liquidity preference theory. According to liquidity preference theory, demand for money is determined by interest rate and income. In other words, there are three motives for holding money; Speculative motive, Precautionary motive, and Transactionary motive. Both precautionary and trasactionary motives are functions of income while speculative motive is a function of interest rate.

$\mathrm{D}^{\mathrm{m}=} \mathrm{f}(\mathrm{r}, \mathrm{Y})$

\subsection{Model Specification}

From the liquidity preference model, the model used from this study is specified. This was done by taking the log of both sides, and adding other control variables. The model is specified below:

LDEMAND $_{\mathrm{t}}=\delta+\beta \mathrm{LGOVT}_{\mathrm{t}}+{ }_{\mathrm{YLASSET}}+\alpha \mathrm{PRIVATE}_{\mathrm{t}}+\pi \mathrm{INT}_{\mathrm{t}}+\mu_{\mathrm{t}}$

Where LDEMAND is the log of demand for money, LGOVT is the log of government domestic borrowing, LASSET is the log of domestic assets, LPRIVATE is the log of credit to the private sector, INT is the interest rate. The data used is monthly data from 2010 to 2016 . All the data were sourced from CBN statistical bulletin. 


\section{Analytical Method}

The analysis was done using the Vector Autoregressive method. The unit root test was used using the ADF and KPSS unit root tests. The co- integration test was established using the Johansen co-integration test.

\subsection{RESULTS PRESENTATION}

The first thing in this analysis is to examine the unit root properties of each variable. This is vital so as to determine the direction of the analysis. This was done using the ADF and KPSS unit root tests.

\subsection{Unit Root Test}

\subsection{ADF testing for the Unit Root of the Variables at level}

The establishment of the presence or absence of unit root in each variable was firstly done by the use of ADF unit root test at the level form for each variable. The result. Shown in Table 1, shows that the probability values of the t-statistics are not significant in for each variable, especially at $1 \%$ and $5 \%$ levels. Similarly, the absolute values of the t-statistics are lower than the absolute values of the critical values of the variables. This shows that each of the variables suffers from unit root problem in their level form.

Table 4.1: ADF Testing for the Unit Root of the Variables at level

\begin{tabular}{|l|l|l|l|l|l|l|}
\hline \multicolumn{7}{|c|}{ ADF Unit Root At Level (Intercept) Max Lag:11 } \\
\hline & t-Statistic & Prob.* $^{*}$ & $\mathbf{1 \%}$ level & $\mathbf{5 \%}$ level & $\mathbf{1 0 \%}$ level & STATUS \\
\hline INT & -2.582105 & 0.1008 & -3.513344 & -2.897678 & -2.586103 & \\
\hline LASSET & -1.780618 & 0.3875 & -3.513344 & -2.897678 & -2.586103 & Unit Root Presence \\
\hline LDEMAND & -2.389943 & 0.1477 & -3.513344 & -2.897678 & -2.586103 & Unit Root Presence \\
\hline LPRIVATE & -1.143763 & 0.6948 & -3.513344 & -2.897678 & -2.586103 & Unit Root Presence \\
\hline LGOVT & -2.704040 & 0.0782 & -3.522887 & -2.901779 & -2.588280 & Unit Root Presence \\
\hline
\end{tabular}

\subsection{ADF Testing for the Unit Root of the Variables After first Differencing}

The establishment of the presence or absence of unit root in each variable was then done by the testing for ADF unit root test at the first differencing form of each variable. The result, shown in Table 2 , shows that the probability values of the t-statistics are significant at $1 \%$ for each variable. Similarly, the absolute values of the $t$-statistics is higher than the absolute values of the critical values of the variables. This shows that each of the variables does not suffer from unit root problem in their first-differencing form.

Table 4.2: ADF testing for the Unit Root of the Variables After first Differencing

\begin{tabular}{|l|c|c|l|l|l|l|}
\hline \multicolumn{7}{|c|}{ ADF Unit Root At Level (Intercept) Max Lag:11 } \\
\hline & t-Statistic & Prob. & $\mathbf{1 \%}$ level & $\mathbf{5 \%}$ level & $\mathbf{1 0 \%}$ level & STATUS \\
\hline INT & $-8.566249 * * *$ & 0.0000 & -3.514426 & -2.898145 & -2.586351 & Unit Root is Absent \\
\hline LASSET & $-11.58844 * * *$ & 0.0001 & -3.514426 & -2.898145 & -2.586351 & Unit Root is Absent \\
\hline LDEMAND & $-8.732327 * * *$ & 0.0000 & -3.515536 & -2.898623 & -2.586605 & Unit Root is Absent \\
\hline LPRIVATE & $-9.235679 * * *$ & 0.0000 & -3.514426 & -2.898145 & -2.586351 & Unit Root is Absent \\
\hline LGOVT & $-11.19038 * * *$ & 0.0001 & -3.525618 & -2.902953 & -2.588902 & Unit Root is Absent \\
\hline
\end{tabular}

** indicates significant at $5 \%, *$ indicates significant at $1 \%$,

\subsection{KPSS Unit Root Test Results At Level}

A further test in the establishment of the presence or absence of unit root test was done using KPSS unit root test. Unlike the case of the ADF unit root test, the significance of the null hypothesis in the case means that there is no unit root. From the Table 3, the values of the adjusted statistics is higher than the critical values, indicating the rejection of the null hypothesis, and accepting the conclusion that the variables contain unit root,

Table4. 3: KPSS Unit Root Test Results At Level

\begin{tabular}{|l|c|l|c|c|l|}
\hline KPSS Unit Root Test Results At Level \\
\hline Variable & t-Statistic & $1 \%$ level & $5 \%$ level & $10 \%$ level & STATUS \\
\hline INT & 1.223816 & 0.739000 & 0.463000 & 0.347000 & \\
\hline LASSET & 64.27353 & 0.739000 & 0.463000 & 0.347000 & Unit Root Presence \\
\hline LDEMAND & 22.88369 & 0.739000 & 0.463000 & 0.347000 & Unit Root Presence \\
\hline LPRIVATE & 70.99629 & 0.739000 & 0.463000 & 0.347000 & Unit Root Presence \\
\hline LGOVT & 2.943619 & 0.739000 & 0.463000 & 0.347000 & Unit Root Presence \\
\hline
\end{tabular}

\subsection{KPSS Unit Root Test Results At First Difference}

After taking the first differencing of the variables, KPSS unit root test shows that the null hypothesis of no unit root presence cannot be rejected, because the adjusted t-statistics is lower than the critically values. The result therefore confirms the earlier results of the ADF unit root test, showing that all the series are I(1) 
Table 4.4: KPSS Unit Root Test Results At First Difference

\begin{tabular}{|l|c|c|c|c|l|}
\hline KPSS Unit Root Test Results At First Difference \\
\hline & Adjusted t-Statistic & $1 \%$ level & $5 \%$ level & $10 \%$ level & STATUS \\
\hline DINT & 0.055206 & 0.739000 & 0.463000 & 0.347000 & Unit Root is Absent \\
\hline DLASSET & 0.033943 & 0.739000 & 0.463000 & 0.347000 & Unit Root is Absent \\
\hline DLDEMAND & 0.010763 & 0.739000 & 0.463000 & 0.347000 & Unit Root is Absent \\
\hline DLPRIVATE & 0.036881 & 0.739000 & 0.463000 & 0.347000 & Unit Root is Absent \\
\hline DLGOVT & 0.033649 & 0.739000 & 0.463000 & 0.347000 & Unit Root is Absent \\
\hline
\end{tabular}

\subsection{Testing Relationship in the Long Run}

Given the findings of the unit root test, it is vital to examine the possibility of a long run relationship among the variables in the model. It is imperative to select a lag length that is optimal for the Johansen co-integration test. Table 5 shows the optimal length of the lag should be one. This was used for the analysis.

Table 4.5: Optimal Lag Length Selection

\begin{tabular}{ccccccc}
\hline \hline Lag & Log L & LR & FPE & AIC & SC & HQ \\
\hline \hline 0 & -79.81004 & NA & $1.02 \mathrm{e}-05$ & 2.692382 & 2.862472 & 2.759279 \\
1 & 114.0551 & 350.8037 & $4.79 \mathrm{e}-08^{*}$ & $-2.668417^{*}$ & $-1.647877^{*}$ & $-2.267033^{*}$ \\
2 & 127.8627 & 22.79343 & $6.93 \mathrm{e}-08$ & -2.313101 & -0.442111 & -1.577232 \\
3 & 158.3417 & $45.47660^{*}$ & $6.06 \mathrm{e}-08$ & -2.487038 & 0.234403 & -1.416682 \\
4 & 174.9668 & 22.16684 & $8.52 \mathrm{e}-08$ & -2.221169 & 1.350722 & -0.816327 \\
5 & 192.5753 & 20.68299 & $1.23 \mathrm{e}-07$ & -1.986518 & 2.435824 & -0.247189 \\
6 & 225.2275 & 33.17048 & $1.18 \mathrm{e}-07$ & -2.229445 & 3.043347 & -0.155630 \\
\hline \hline
\end{tabular}

* indicates lag order selected by the criterion

LR: sequential modified LR test statistic (each test at 5\% level)

FPE: Final prediction error

AIC: Akaike information criterion

SC: Schwarz information criterion

HQ: Hannan-Quinn information criterion

\subsection{Johansen Co-integration Test}

As shown in Table 6, the Trace and Maximum Eigen value of the Johansen Co-integration test reveals the presence of no co-integration equations in the long run. This means that the variables do not have long run relationship. Given the results of the no co-integrating relation, the need to estimate unrestricted vector autoregressive (VAR) is necessitated 
Table 4.6 : Co-integration Test for Long Run Relationship Unrestricted Co-integration Rank Test (Trace)

\begin{tabular}{|c|c|c|c|c|}
\hline Unrestricted Co-integration Rank Test (Trace) & & \\
\hline Hypothesized & & Trace & $\mathbf{0 . 0 5}$ & \\
\hline No. of CE(s) & Eigenvalue & Statistic & Critical Value & Prob. $^{* *}$ \\
\hline None & 0.323490 & 62.69399 & 79.34145 & 0.4539 \\
\hline At most 1 & 0.206585 & 34.94660 & 55.24578 & 0.7657 \\
\hline At most 2 & 0.141504 & 18.51655 & 35.01090 & 0.7955 \\
\hline At most 3 & 0.087381 & 7.683852 & 18.39771 & 0.7151 \\
\hline At most 4 & 0.016646 & 1.191806 & 3.841466 & 0.2750 \\
\hline
\end{tabular}

Trace test indicates no cointegration at the 0.05 level

* denotes rejection of the hypothesis at the 0.05 level

**MacKinnon-Haug-Michelis (1999) p-values

Unrestricted Cointegration Rank Test (Maximum Eigenvalue)

\begin{tabular}{|c|c|c|c|c|}
\hline Hypothesized & Max-Eigen & 0.05 & Prob.** \\
\hline No. of CE(s) & Eigenvalue & Statistic & Critical Value & 0.3954 \\
\hline None & 0.323490 & 27.74739 & 37.16359 & 0.8215 \\
\hline At most 1 & 0.206585 & 16.43005 & 30.81507 & 0.8530 \\
\hline At most 2 & 0.141504 & 10.83270 & 24.25202 & 0.7672 \\
\hline At most 3 & 0.087381 & 6.492046 & 17.14769 & 0.2750 \\
\hline At most 4 & 0.016646 & 1.191806 & 3.841466 & \\
\hline Max-eigenvalue test indicates no cointegration at the 0.05 level & \\
\hline * denotes rejection of the hypothesis at the 0.05 level \\
\hline **MacKinnon-Haug-Michelis (1999) p-values
\end{tabular}

\subsection{Unrestricted Vector Autoregressive (VAR) Result}

One important way to interpret the VAR result is through the impulse response function. The unrestricted VAR also helps to examine the response of the dependent variables to changes in the independent variables in the model. This is presented in this section. The impulse response function helps to interpret the results of the VAR model. It shows how demand for money responds to shock in its self, shock in interest rate, shock in credit to private sector, shock in credit to government, and shock in domestic assets. As shown in Figure 1, all the independent variables are significant in determining the demand for money. The result shows that the response of demand for money was initially positive to credit to government until the third period, and then became negative. An explanation for this is that as government borrows more money from the economy to spend, inflation increases, making consumers willing to hold more money. However, with time, increased government spending leads to higher interest rate. This will ultimately decrease demand for money because consumers will want to benefit from higher interest rate, and reduce the amount held for idle use.

Similarly, the result is also similar with that of the credit to the private sector. The more credit access consumers have, the more money they have access to for idle usage. Similarly, the demand for money responds negatively to shock in domestic asset. Domestic asset is interest generated, and the more domestic assets are acquired by consumers, the less is demand for money. This shows that domestic assets have a negative effect on demand for money. The result is also similar with the effect of interest rate on demand for money. Demand for money responds negatively to shock in demand for money. In order words, an increase in interest rate will have a negative effect on demand for money. 

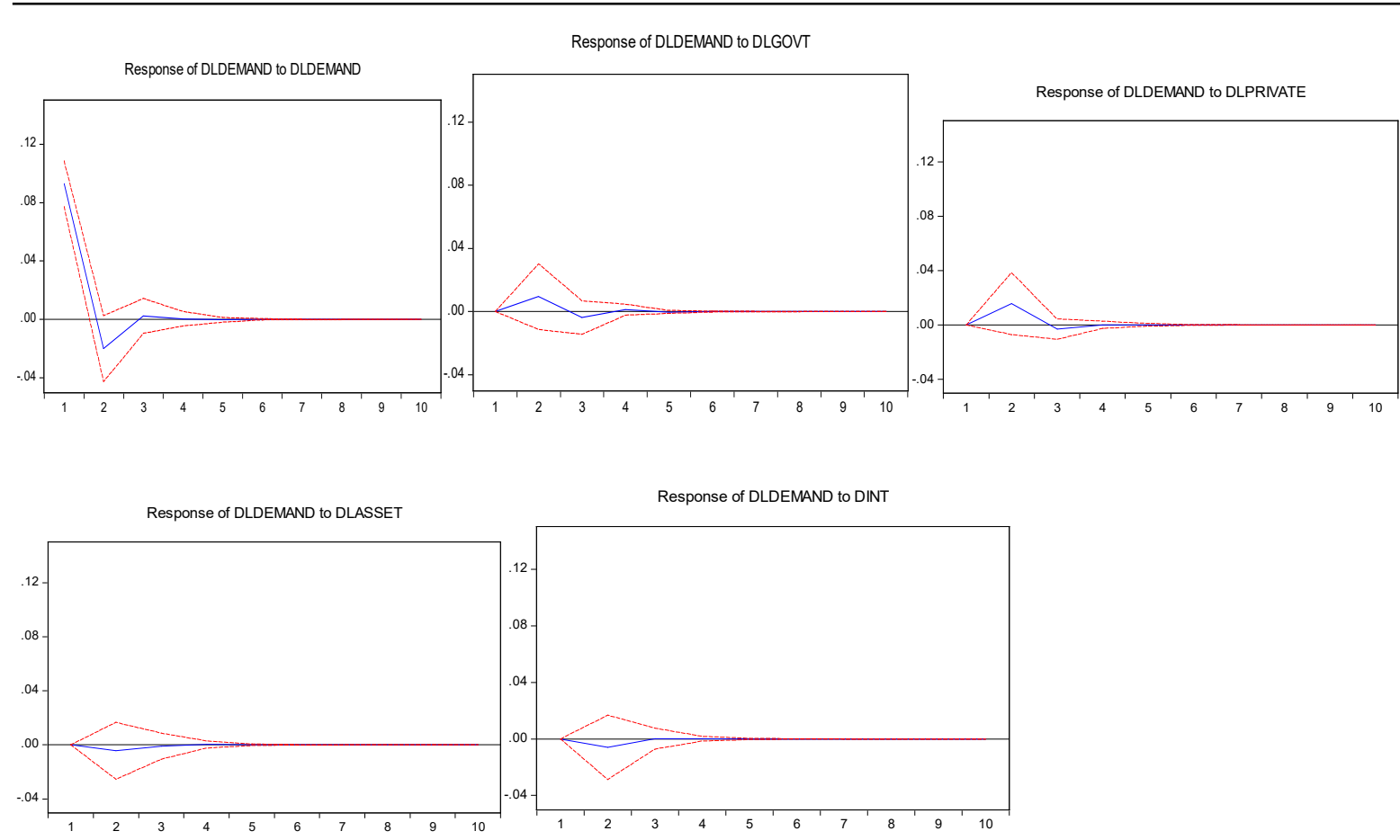

Figure 1: Impulse Response Function of Demand for Money

\subsection{VAR Granger Causality Test Results}

The Unrestricted VAR also indicates short run causality among the variables. This is presented in this section. The result shows that there is no causality between government borrowing and demand for money. However, there is a unidirectional causality from demand for money to credit to private sector. More so, there is a unidirectional causality running from demand for money to domestic assets. In other words, it is demand for money that granger causes demand for assets. There is however no causality found between interest rate and demand for money.

Table 4.8:VAR Granger Causality Test Results

\begin{tabular}{|l|c|l|l|}
\hline Ho( Null Hypothesis) & Chi-sq & Prob. & Direction of Causality \\
\hline DLGOVT does not Granger cause DLDEMAND & 0.868937 & 0.3512 & No Causality \\
\hline DLDEMAND does not Granger cause DLGOVT & 0.990316 & 0.3197 & No Causality \\
\hline DLPRIVATE does not Granger cause DLDEMAND & 1.884412 & 0.1698 & No Causality \\
\hline DLDEMAND does not Granger cause DLPRIVATE & $4.437859^{* *}$ & 0.0352 & Causality \\
\hline DLASSET does not Granger cause DLDEMAND & 0.135490 & 0.7128 & No Causality \\
\hline DLDEMAND does not Granger cause DLASSET & $7.735855^{* *}$ & 0.0054 & Causality \\
\hline DLINT does not Granger cause DLDEMAND & 0.277829 & 0.5981 & No Causality \\
\hline DLDEMAND does not Granger cause DLINT & 0.881427 & 0.3478 & No Causality \\
\hline
\end{tabular}

** indicates significant at $5 \%, *$ indicates significant at $1 \%$,

\subsection{Conclusion and Recommendation}

\subsection{Conclusion}

This study investigates the macro economic analysis of the demand for money. The Data for the period 2010 to 2016 was used. The time series characteristics of the model were examined using the ADF and KPSS unit root tests as well the Co-integration and VAR tests to determine whether a long run relationship exist between the variables of interest.

The results obtained were quite commendable in the sense that most of the variables conform to a priori expectation about their signs. The result under the ADF testing shows that the probability values of the t- statistics are significant at $1 \%$ for each variable signifying that each of the variables does not suffer from unit root problem in their first - difference. The significance of the null hypothesis in the KPSS Unit root test means that there is no unit root since the adjusted statistics is higher than the critical values, and this indicates a rejection of the null hypothesis and accepting the conclusion that the variables contain unit root. The Johansen co- integration test reveals that there are no co-integration equations in the long run. This explains that the variables do not have long run relationship. Looking at the VAR model, the demand for money responds to shock in itself, shock in interest rate, shock in credit to private sector, shock in credit to government, and shock in domestic assets. This explains that as government borrows more money from the economy to spend, inflation increases, making consumers 
willing to hold more money.

\subsection{Recommendations}

The monetary authorities in Nigeria should introduce the proper monetary policy along side an improved fiscal discipline. This implies formulating policies towards redistributing income, financial development, exchange rate stability stable and growing stock market.

The Central Bank of Nigeria should put in place monetary policy that would ensure that the volume of money in circulation does not exceed the demand for money. This will create efficiency in the demand for and supply of money and thus lead to equilibrium in aggregate demand and aggregate output with sustainable economy growth on the economy as a whole.

The interest rate policies needs to be reformed towards market principles in order to improve the effectiveness of Monetary Policy as a result of Nigeria's increasing integration into the world economy.

\section{References}

Adejugbe, M.D. (1989). "The demand for money in Nigeria: Further Considerations" Nigeria Journal of Economics and social studies_30.215-229

Ajayi, S.I. (1974). The demand for Money in Nigerian Economy: Comments and Extension. The Journal of Economics and Social Studies.

Ajayi, E.A. (2006). Some empirical evidence on the demand for money in Nigeria. The American Economist, 5154.

Akinlo, E.A. ( 2006). The stability of money demand in Nigeria: an autoregressive Distributed lag approach. Journal of Policy Modeling, 445-452.

Alayande, B.A. (2004). "The Demand for money in Nigeria: a micro Foundation Approach."

Anorou, E.M. (2002). "Stability of the Nigerian M2 Money Demand function the SAP Period.

Arrau, P.D Gregorio (1991). "Financial Innovation and Money Demand; Theory and Empirical Implementation.

Asogu, J.O and C.N,O) Mordi (1987). " An Econometric Model of the Nigerian Monetary Sector: Outline and Preliminary results, Mimeo, Central Bank of Nigerian.

Baba, Y., Hendry, D.F. and Starr, R.M. (1992). "The Demand for M1 in the United States of America., 19601988". Review of Economics studies 95,25-61

Baharumshah, A., Mohd, S., and Yol, M. (2009). Stock prices and demand for money in China New Evidence. International Financial Market Institutions and Money, 171-187.

Bassey, E.B., P.K. Besong, and C. Effiong (2012). The effect of Monetary Policy on Demand for Money in Nigeria, interdisciplinary Journal of Contemporary Research in Business, Vol. 4, No 6

Baumol E. J. (1952). "The Transactions Demand for Cash: An Inventory theoretic Approach.” Quarterly Journal of Economics, Vol. 66, November, PP 545.56

Bitrus, Y.P. (2011). The Demand for Money in Nigeria, European Journal of Business and Management, Vol. 3, No. 6

Brown, R., J. Durbin, and J. Evans (1975),Techniques for testing the Constancy of Regression Relations Over Time. Journal of the Royal Statistical Society.

Bomberger, W.A. and Mackinon, G.E (1980). "Money Demand in Open Economics" Alternative Specification" Southern Economics Journal, 47: 39-40

Busari, D.T. (2006): "Stability of the Demand for money function in Nigeria," CBN Economic and Financial Review, Vol. 42. No 3, P.49-68

Caporale, G.M. and Gil- Alana, L.A. (2005). "Fractional Cointegration and Aggregate Money Demand Functions," The Manchester School 73,737-753

Ditimi, A., Wosa P.I and Olaiya, S.A.(2011). “An Appraisal of Monetary Policy and its effect on Macro Economic Stabilization in Nigeria". Journal of Emerging Trends in Economics and

Management Sciences (JETEMS) 2 (3): 232-237

Doguwa, S., Olowofeso, O.E., Uyaebo, S.O., Adamu, I., and Bada, A.S. (2014). Structural breaks, cointegration and demand for money in Nigeria. CBN Journal of Applied Statistics 5.1, 15-33.

Dutkowsky DH, Atesoglu HS (2001). The Demand for Money: A Structural Econometric Investigation. South Econ. J. 68(1)

Friedman, M. (1988). Money and Stock markets on money demand. Journal of political economy, $221-245$.

Goldfeld, Stephen M, James Duesenberry, Willian Poole (1973). The Demand for money Revisited. Brookings Papers on Economic Activity. 1973(3): 577-646.

Hafer, R., and Kutan, A.(1994). Economic reforms and long run money demand in China: implications for monetary policy. Southern Economic Journal, 946-945.

Hagan A. (2006). Estimates of the Money Demand function in Ghana. West African Journal of Monetary and Economic Integration. December 6(2): 15-36. 
Hamburger, M. J. (1966). "The Demand for Money by Households, Money Substitutes and Monetary Policy" Journal of political Economy, No 74 P. 616.

Hassan, K. M., Choudhury, k., and Waheeduzzaman, M. (1995). On black market exchange rate and demand for money in developing countries: The case of Nigeria. Atlantic Economic Journal, 35-44.

Iyoha, M. A. (1975). "The Demand for Money in Nigeria". Nigerian Journals of Economic and Social Studies" 11:386-296.

Jimoh, A. (1990). "The Demand for Money and the Channels of Monetary Stock transmission in Nigeria." The Nigerian Journal of Economics and Social Studies 32 (1)

Judd, J.P. and Scadding, J. L. (1982). "The Search for a Stable demand for Money function". A survey of the Post 1973 Literature. Journal of Economic Literature Vol. xx, 993-1023.

Keynes, J. M. (1936):”The general Theory of Employment, Interest and Money”. London and New York Macmillan.

Kumar, S., Webber, D.J., and Fargher, S. (2010). Money Demand Stability: A case study of Nigeria.

Laidler, D. E. W. (1977). The Demand for Money: Theories and Evidence. New York : Harper And Row. (2nd Edition).

Lee, T.H. (1967): "Alternative Interest Rates and the Demand for Money", the Empirical Evidence" American Economic Review. Vol.V11, P. 1174.

Mankiw, N. G and Summers, L.H. (1986). "Money Demand and the Influence of Fiscal Policies.”Journal of Money Credit and Banking. 18: 415-429.

Nell, K.S. (1999). The Stability of Money Demand in South Africa, 1965-1977. Department of Economics, University of kent at Canterbury. No 99/5.

Odama, J. S.(1974). "The Demand for Money in the Nigerian Economy”, NJESS 16(1) March, 178-188.

Ojo, O. (1974). The Demand for Money in the Nigerian Economy: Some Comments. Nigerian Journal of Economic and Social Studies, 16(1), 149-152.

Omanukwe, P. N. (2010). The Quantity Theory of Money: Evidence from Nigeria. Economic and Financial Review 48.2, 91-107.

Omotor, D.G. and Omotor, P. E. (2011). "Structural Breaks, Demand for Money and Monetary Policy in Nigeria". www.google.com.ng

Oresotu, F. O., and Mordi, C. N. (1992). The demand for money function in Nigeria: An empirical investigation. Central Bank of Nigeria.

Owoeye, O. and Onafowora, O. A. (2007). "Structural Adjustment and the Stability of the Nigerian Money Demand Function.” International Business and Economics Research Journal Volume 3, Number 8.

Teriba, O. (1974). "The Demand for Money in the Nigerian Economy: Some methodological issues and further evidence". Nigerian Journal of Economic and Social Studies. 401, 16, No. 1, Pp. 153-164.

Tiegen, R. (1971). The demand and supply for money. Reading in money, National income and Stabilization policy.

Teriba, O. (1973).“The Demand for Money in Nigeria”. Economics Bulletin of Ghana. Second series, 3(4) p. 1422

Teriba, A.O. (1992). "Modeling the Demand for Money in Nigeria: An Application on Co- integration and Error Correction techniques (1960-1989)"

Tomori, J. (1972). “The Demand for Money in Nigeria: Nigeria Journal of Economics and Social Studies (NESS) 4 (3) November. 